\title{
REFLEXÕES SOBRE ARTE E INDÚSTRIA CULTURAL
}

\author{
REFLECTIONS ON ART AND CULTURE INDUSTRY \\ RÉFLECTIONS SUR L'ART ET L'INDUSTRIE CULTURELLE \\ REFLEXIONES ACERCA DEL ARTE Y DEL INDUSTRIA CULTURAL
}

Maria José Dozza Subtil *

\section{RESUMO}

No presente texto discute-se a relação entre arte-particularmente a música - e Indústria Cultural, considerando-se as contradições inerentes a essa idéia formulada pelos autores frankfurtianos. Entendendo-se o campo cultural em que se situam os objetos musicais como um espaço de relaçôes e de disputas pelo poder simbólico, discutem-se os gêneros erudito, popular e massivo, apontando-se para o hibridismo desses conceitos, tendo em vista os imperativos da sociedade capitalista de consumo. Também se historiciza, no texto, a produção, circulação e consumo artístico, enfocando-se novas possibilidades de fruição pela reprodutibilidade técnica dos objetos estéticos. Por fim, apresenta-se uma reflexão sobre a necessária relação entre fruição, consumo e formação a partir do ponto de vista adorniano, que considera a substituição da dimensão instrumental da razão pela dimensão emancipatória como condição para a desalienação.

Palavras-chave: Arte. Indústria Cultural. História da produção estética. Formação.

* Doutora em Engenharia de Produção - Mídia e Conhecimento - pela Universidade Federal de Santa Catarina (UFSC, 2003). Mestre em Educação. Licenciada em Arte. Atua como pesquisadora e orientadora no Mestrado em Educação da Universidade Estadual de Ponta Grossa - PR (mjsubtil@gmail.com). 


\section{INTRODUÇÃO}

Adorno (1991), na obra O Fetichismo da Música e a Regressão da Audição, e Benjamin (1982), em seu trabalho A Obra de Arte na Época de sua Reprodutibilidade Técnica, apontaram, já nas primeiras décadas do século XX, a contradição que cerca o consumo e a fruição dos objetos culturais veiculados pela Indústria Cultural. O primeiro concebe a música massiva e popular como mercadoria - fetiche - que não permite ao homem uma aproximação consciente, racional e livre, mas apenas um re-conhecimento, pela repetição e estandartização. Adorno afirma a aura da "música séria" por "seu próprio valor intrínseco" (1991, p. 80).

Walter Benjamin diz que a reprodução da arte pelos meios técnicos é um processo positivo, pois permite a todos a fruição do que era historicamente restrito e único. Contrariando Adorno, o autor desconstrói a "aura" da obra de arte, validando os meios eletrônicos como reprodutores e como instauradores de uma nova sensibilidade, o que se constitui num fato político.

No caso aqui enfocado - a música -, essas duas dimensões antagônicas e complementares sobre o consumo de arte permanecem como balizadoras da contradição que cerca até hoje o uso das mídias, ${ }^{1}$ em especial a televisiva.

Com o objetivo de compreender as práticas, o consumo, o gosto musical e as mediações da sociedade e da mídia nesse processo, Subtil (2003) pesquisou a apropriação da música midiática ${ }^{2}$ por crianças de 9 a 12 anos. A autora constatou nesse estudo que, independentemente de gênero e classe social, a maioria dos participantes da pesquisa, inclusive professores entrevistados, consumia com prazer as músicas, programas e novelas, porém no discurso manifestava uma reprovação sistemática a esses mesmos objetos, por considerá-los "inadequados", "de baixa qualidade" e "massivos".

Evidenciou-se a contradição apontada anteriormente e a distinção entre "o bom gosto musical", identificado com a música erudita ou com os grandes nomes da Música Popular Brasileira - MPB,$^{3}$ e a música de "baixa qualidade", que poderia ser identificada com a música massiva ou "brega", "cafona" e kitsch (CHAUÍ, 1985; ECO, 1976).

Não há como negar que uma massificação musical atinge a todos indistintamente, uma vez que a TV e sua sonoridade/visualidade são onipresentes - e essa afirmativa denota concordância com o que diz Adorno. Por outro lado, essa produção cumpre um papel socializador e distribuidor de diferentes formas culturais, em especial no que se refere à música, diluindo o caráter dual de cultura das elites e cultura das massas, concordando-se agora com Benjamin.

Contemporaneamente, autores como Canclini, Santaella e Martin-Barbero, cujas formulaçôes são apropriadas para aprofundar o debate proposto neste texto, analisam a dialética da função social, política e cultural das mídias. Bourdieu é chamado para contribuir com essa reflexão através dos conceitos de campo, habitus e poder simbólico, 
que embasam a noção de gosto musical, cultura e cultura medianizada, idéias básicas na compreensão da relação entre mídias e arte.

Ressalte-se a necessidade de remeter esse debate para a educação escolar, visto que as mídias em geral e a música em particular são produtos datados e situados e concorrem para a produção de sentidos sobre o mundo e a sociedade. Também é preciso enfatizar, numa via de mão dupla, os meios de comunicação e a cultura deles decorrente, pois são objetos de conhecimento (o que veiculam e como) e objetos para o conhecimento (recepção ativa e produtiva) (SUBTIL, 2003, p. 4).

No livro Educação e Emancipação, Adorno (1995, p. 121) afirma: "A educação tem sentido unicamente como educação dirigida a uma auto-reflexão crítica". O presente trabalho faz algumas reflexões sobre cultura, arte/música na interface com o conceito de Indústria Cultural, com o propósito de embasar um debate de que a escola não pode se ausentar, sobre o necessário papel da formação para o usufruto dos meios e dos produtos culturais contemporâneos.

\section{O CAMPO DA PRODUÇÃO CULTURAL - REFLEXÕES SOBRE CONCEITOS}

\section{I.I A noção de campo cultural em Bourdieu: possíveis explicações para o consumo midiático}

A noção de campo enquanto um constructo teórico que estabelece uma dimensão relacional de compreensão da realidade, ou seja, "uma estrutura de relaçōes objetivas" (BOURDIEU, 1989, p. 66), vem retirar do arbitrário e do natural a produção, veiculação, usos e consumo dos bens simbólicos. Nesse espaço social, "os agentes se enfrentam, com meios e fins diferenciados conforme sua posição na estrutura do campo de forças, contribuindo assim para a conservação ou a transformação de sua estrutura" (BOURDIEU, 1997, p. 50).

O autor situa as diferenças (distinçōes) entre os sujeitos não apenas como derivadas dos antagonismos de classe; ressalta que elas são decorrentes do capital cultural adquirido por familiarização ou aprendizagem escolar com mediação decisiva dos habitus disposiçôes incorporadas. Essa distinção não ocorre num vácuo, mas nos espaços relacionais - campos - que estabelecem posiçôes dominantes ou dominadas resultantes das lutas pela legitimação do poder simbólico, para estabelecer o que é válido, ou não, para ser apropriado e o que produz rentabilidade simbólica (cultural, social e econômica). O cenário desse embate por validação de posições nos diversos campos é a estrutura, o sistema ou a sociedade econômica, política e social em que os sujeitos se inserem.

As classes sociais não são definidas apenas pelo capital econômico, mas pelo acesso diferenciado ao capital cultural - bens, capacidades e títulos culturais que resultam no poder simbólico. Esse é um poder substitutivo da força física ou econômica, de fazer ver e fazer crer, de confirmar ou de transformar a visão e, conseqüentemente, a ação sobre o 
mundo. Ele só se exerce se for reconhecido, isto é, ignorado como arbitrário (BOURDIEU, 1992, p. 14).

Nessa perspectiva, de um lado temos a produção erudita num espaço de certa forma delimitado, no qual as obras circulam entre os que dominam os códigos de acesso; de outro, o campo da Indústria Cultural, organizado tendo em vista os não-produtores, ou seja, o público consumidor (BOURDIEU, 1992, p. 14).

Essa noção traz a diferença fundamental entre dois tipos de produção: a arte média e genérica destina-se a um público médio, socialmente heterogêneo, que define as obras a serem consumidas - os institutos de pesquisa revelam bem os requerimentos desse público - sob a sanção do mercado econômico; e a "arte pela arte" é destinada aos produtores, um público que possui disposiçōes propriamente estéticas, instrumentos culturais de fruição e apreciação, o capital cultural.

Nesses locus das disputas por legitimidade dos sujeitos e dos objetos, mais do que a dominação econômica, está em jogo o poder de estabelecer o que é "brega" ou "chique", o que está na moda, os hit parades, quem é o artista a ser consumido, quais os estilos do momento, ou seja, a dominação simbólica. No entanto, o processo de medianização promovido pela indústria cultural explicaria os gostos musicais semelhantes dos públicos econômica e socialmente diferenciados. Como se trata de uma lógica baseada na produção industrial, essa medianização produz o que Bourdieu denomina de "rentabilidade dos investimentos e, em conseqüência, da extensão máxima de público" (1997, p. 137).

Entendendo-se o campo cultural em que se situam os objetos musicais como um espaço de relações e de disputas pelo poder simbólico, os diferentes conceitos de cultura serão discutidos a seguir, a partir dessa percepção.

\section{I.2 Cultura e culturas - as imbricações dos conceitos}

Para Chauí (1985, p. 14):

Em sentido amplo, cultura é o campo simbólico e material das atividades humanas... Em sentido restrito, isto é, articulada à divisão social do trabalho, tende a identificar-se com a posse de conhecimentos, habilidades e gostos específicos, com privilégios de classe, e leva à distinção entre cultos e incultos, daí a diferença entre cultura letrada erudita e cultura popular.

A cultura popular é assim entendida a partir de diferenças em movimento no interior das classes sociais que a dotam de sentidos e significados diferentes em cada classe. A autora compreende "a dimensão cultural popular como prática local e temporalmente determinada, como atividade dispersa no interior da cultura dominante, como mescla de conformismo e resistência" (CHAUÍ, 1985, p. 43).

Questionando o enfoque que considera a cultura ou as culturas como "reflexo" das relaçôes econômicas, Santaella (1990, p. 35) afirma não ser possível estabelecer uma relação unívoca entre infra e superestrutura, porque os fenômenos culturais são fortemente 
midiatizados em relação ao fator econômico, estendendo-se ao político-cultural: "Cada uma dessas dimensões é uma unidade complexa praticamente autônoma de práticas diferenciais determinadas pelo econômico em última instância”.

Canclini (1984) diz que a arte culta, ou arte erudita, tem origem na burguesia, contempla também setores intelectuais da pequena burguesia e privilegia o momento da produção como criação individual. $\mathrm{O}$ consumo acontece pelo recolhimento e pela elevação. Não há necessidade de problematizar a obra, basta "colocar-se em atitude de contemplação" (p. 49). A forma de aproximação à música erudita, para citar um exemplo, supõe a valorização da "grande música" ou a aclamação dos artistas consagrados pela crítica, além, é claro, do conhecimento formal sobre obras e compositores, um capital cultural distintivo de classe.

A arte para as massas fundamenta-se no segundo momento do processo artístico, que é o da distribuição. Ela é produzida pela classe dominante, no caso da música, em especial as gravadoras, os canais de TV, especialistas (produtores, autores, críticos musicais) e tem como finalidade transmitir uma ideologia de consumo padronizado e fruição passiva. A distribuição é o elemento chave nesse tipo de arte, tanto por questóes ideológicas quanto por questões econômicas. Interessa a quantidade de pessoas que vão ser atingidas e o potencial de consumo. (CANCLINI, 1984). Esse é um processo que se evidencia na música quando as gravadoras lançam um sucesso e o distribuem através das rádios, novelas, programas de auditório, revistas musicais e midiáticas, shows, comerciais, etc.

Por outro lado, hoje há clareza da imbricação e transformação dos modos de ser da cultura pelo intenso trânsito entre o popular, o folclórico e o culto, não só na música:

... o popular não se define a priori, mas pelas estratégias instáveis, diversas, com que os próprios setores subalternos constroem suas posições, e também pelo modo como o folclorista e o antropólogo levam à cena a cultura popular para o museu ou para a academia, os sociólogos e os políticos para os partidos, os comunicólogos para a mídia (CANCLINI, 1997, p. 23).

Para Canclini (1997), há uma transformação das relações entre tradição e modernismo cultural e a modernização econômico-social na América Latina, a qual resulta em "culturas híbridas" (p. 23). O autor defende a idéia de que, "em relação ao culto, ao popular e ao massivo, é preciso elaborar um pensamento mais aberto para abarcar as interações e integraçôes entre os níveis, os gêneros e formas da sensibilidade coletiva" (p. 28).

Segundo Micelli (1982, p. 43), é necessário também relativizar a oposição existente no campo simbólico entre cultura erudita e Indústria Cultural, numa formação social como a do Brasil, em que, embora se reconheça objetivamente a imposição de um arbitrário cultural,

não é possível afirmar a existência de uma estrutura de classes unificada, e muito menos de uma classe hegemônica - correspondente local da 'burguesia' em condiçôes de impor ao 
sistema inteiro sua própria matriz de significações. Estamos diante de um campo simbólico fragmentado, não havendo nenhuma fração da coalizão dominante em condiçôes de impor a legitimidade de sua visão de mundo às demais classes.

A partir do que até aqui foi exposto, propõe-se refletir com maior profundidade sobre o campo artístico e os processos de produção, fruição e consumo dos objetos estéticos, em particular no que se refere à música.

\section{ARTE/MÚSICA E INDÚSTRIA CULTURAL - FRUIÇÃO ${ }^{4}$ E CONSUMO $^{5}$}

\section{I Arte: produção e circulação}

O homem estabelece relações de diferentes naturezas com o mundo humano social. O fabrico de um pote, por exemplo, que tem como objetivo armazenar água, produz uma relação de caráter prático utilitário. Esse objeto pode possuir enfeites, ser colorido, conter elementos decorativos; isso não vai alterar a função do pote, mas traduz o caráter estético das relações dos homens entre si e com a natureza. (CANCLINI, 1984; FISHER, 1987).

Fica evidente que um simples objeto revela necessidades espirituais que transcendem o imediatismo da prática:

(...) a vida não necessita de artifícios para poder manter-se. O homem, no entanto, embelezaa e adorna-se. Não aceita nem o seu próprio corpo como simples realidade natural, e a prova disso é que o enfeita. A tudo que é útil, vaso ou arma de guerra, acrescenta o colorido, a linha e a figura. Transforma o movimento em dança, o grito em canto... (NUNES, 1966, p. 80).

Portanto, não se pode falar em "arte", mas em "artes", tantas quantas são as manifestações de humanização do homem, em terrenos tão diversos quanto a pintura, a música, o teatro, o cinema, a escultura, a grafitagem e a arte digital.

Deduz-se, do acima exposto, que através do trabalho artístico o homem cria não apenas coisas, mas relaçóes que satisfazem uma necessidade essencialmente humana de objetivar sua dimensão espiritual, tornando-a sensível nas formas artísticas. Nesse processo ele potencializa as capacidades espirituais para além da prática criadora e transformadora já existente no trabalho em geral, ao mesmo tempo em que humaniza a natureza (VAZQUEZ, 1978).

O caráter social da produção artística só se realiza quando ela é fruída pelos outros, porque a obra existe para ser consumida, para ser comunicada para além das barreiras do tempo e do espaço. O fruidor capta essa experiência identificando-se com ela, reconhecendo nela os atributos de humanidade que o autor soube incorporar. Portanto, a arte só tem um significado quando outros se apropriam dessa significação (VAZQUEZ, 1978). 
Dufrenne (1976, p. 63) explica a relação entre arte e público a partir de três épocas: a primeira, em que o público era a comunidade social em sua totalidade; a segunda, na qual a produção artística é apropriada restritamente por grupos e classes sociais aos quais ela se destinaria; a terceira, em que se observa o desenvolvimento dos meios técnicos de reprodução, o que vai implicar uma transformação não só da relação das obras com o público, mas do próprio público e das obras.

Horkheimer e Adorno (1982) criam a expressão Indústria Cultural como processo de industrialização que organiza a produção artística e cultural no contexto das relações capitalistas de produção, para ser lançada no mercado, vendida e consumida como qualquer mercadoria. Assim, valores espirituais, artistas, pensadores, idéias, obras de arte passam por um nivelamento, uma padronização que ajusta o valor de uso ao valor de troca. Os autores denunciam a forma sistêmica dessa organização: "A civilização atual a tudo confere um ar de semelhança. Filmes, rádio e semanários constituem um sistema. Cada setor se harmoniza e todos se harmonizam entre si." (HORKHEIMER; ADORNO, 1982, p. 159).

Para os autores, a Indústria Cultural é o golpe de misericórdia nos ideais do esclarecimento, ao instaurar os imperativos da sociedade administrada, anulando toda e qualquer brecha para a autonomia do sujeito na produção e fruição da cultura e na reflexão sobre sua própria condiçãoo humana (HORKHEIMER; ADORNO, 1982, p. 159).

Walter Benjamin, embora ligado ao mesmo grupo de pensamento - a Escola de Frankfurt -, contesta essa visão extremamente pessimista em relação aos meios tecnológicos de difusão e comunicação. $\mathrm{O}$ autor considera que a aura - "única aparição de uma realidade longínqua, por mais próxima que ela possa estar” (1982, p. 215) - é a essência da fruição artística cultual e o que atesta a "autenticidade" da obra de arte. A possibilidade de multiplicação vai subverter esse distanciamento, desnudando o objeto artístico, presentificando-o e destituindo o seu caráter sagrado e ritual. $O$ que foi produzido uma única vez, ao ser reproduzido, constitui-se num fenômeno de massa que vai além do consumo privado. Para Benjamin (1982, p. 217): "A obra de arte, na era de sua reprodutibilidade técnica revoluciona o estatuto da cultura, dissolve o conceito burguês de arte, transforma a cultura de elite em cultura de massa”.

Outra tese importante defendida por Benjamin é a de que há uma nova forma de aproximação aos objetos da arte gestada pelo acesso tecnológico. Referindo-se ao cinema, ele diz:

[...] a partir do momento em que a obra fica excluída da atmosfera aristocrática e religiosa, que fazem dela uma coisa para poucos e um objeto de culto, a dissolução da aura atinge dimensões sociais. Essas dimensões seriam resultantes da estreita relação entre as transformações técnicas da sociedade e as modificações da percepção estética (BENJAMIN et al., 1983 , p. XI). ${ }^{6}$ 
Cabe, agora, aprofundar as relações entre o campo artístico e o campo da Indústria Cultural, que é o espaço de circulação dos produtos musicais privilegiado no texto, tendo em vista as contradiçōes apontadas anteriormente.

\subsection{Campo artístico e Indústria Cultural}

Em primeiro lugar, é importante compreender o conceito de mediação em Adorno, entendendo-o na relação que esse autor estabelece entre arte e Indústria Cultural. Para ele, “(...) há mediação da sociedade na obra de arte, vale dizer, componentes fundamentais do processo histórico-social do interior do qual a obra de arte é produzida estão incorporados nela, na forma da obra" (ADORNO, 1986, p. 20). Assim, se a mediação não é externa, está no interior da obra de arte; ela é, então, “(...) a antítese social da sociedade, não deve imediatamente deduzir-se desta” (ADORNO, 1988, p. 19). Enquanto momento sensível (dimensão da sua positividade), a arte expõe a realidade, ao mesmo tempo em que, paradoxalmente, a nega (pela transfiguração recriadora do real). Condicionada pelo tempo histórico e expressa em objeto artístico, a arte internaliza as contradições sociais externas, negando e rompendo os limites materiais que a configuram.

Há uma distinção fundamental entre a lógica interna da obra de arte - a mediação da negatividade que constitui a sua autonomia - e a lógica interna da Indústria Cultural, que se submete aos imperativos econômicos e mercadológicos do sistema social no qual se insere. A relação imediata da Indústria Cultural com a realidade é afirmação, nada é negado, tudo se reitera e se mantém. (ADORNO, 1988 p. 26). Isso traz a alienação e a satisfação passageira, o gozo fugaz, sem compromisso e sem o aporte da razão e da reflexão necessárias para uma compreensão radical do real. ${ }^{7}$

Segundo Oliveira (1998, p. 61), importa um esclarecimento quanto ao termo mediação, usado por Adorno no sentido hegeliano, isto é, considerando as mediações como "intrínsecas ao objeto, não sendo, portanto, construídas entre este e os outros objetos dos quais é aproximado". O autor explica as formulações de Adorno dizendo que os produtos da Indústria Cultural mantêm relações imediatas com o todo, objetivando reafirmá-lo (positividade apenas). O objeto cultural autêntico, na qualidade de obra singular, traz em si elementos capazes de negar o todo (negatividade), contribuindo assim para a sua transformação (OLIVEIRA, 1998).

Oliveira (1998) traz outra constatação de Adorno que afirma a dupla contradição da Indústria Cultural: não é indústria, porque só contém a lógica da distribuição; e não é cultura, porque não obedece à lógica interna da produção cultural, inexistindo qualquer processo mediador entre os pólos da indústria e da cultura.

Cabe ressaltar as contradiçóes inerentes aos conceitos até aqui explicitados. A negação da possibilidade de que os produtos da Indústria Cultural possuam o caráter de "verdadeira arte", insistentemente defendida por Adorno, é construída a partir do: 
[...] fato de que a obra de arte autêntica e autônoma, característica da cultura burguesa, continha um valor de verdade que transcendia as precárias condiçóes da existência material dos homens. Ao falar de um mundo distante e irrealizável no plano da ordem material, a obra de arte burguesa protestava contra a ordem vigente (SILVA, 1999, p. 31). ${ }^{8}$

Transcendendo a realidade imediata, a arte cumpre sua função reveladora, o que seria impossível numa experiência estética regressiva, padronizada. Ora, é evidente aqui a dicotomia entre razão e emoção, diversão e esclarecimento. Nessa perspectiva, é negada às massas a faculdade de reflexão.

Coelho (1980, p. 23) afirma que tal preconceito leva a um equívoco, o de "confundir o veículo cultural com a ideologia que rege seu uso; a linguagem do veículo com sua ideologia e a realidade de uso com as possibilidades de uso do veículo".

Nessa linha de pensamento voltemos a Benjamin (1982), que vai discutir a Indústria Cultural considerando o caráter progressista dos meios, buscando não contrapô-la à arte, mesmo concordando com a tese da submissão dos meios aos imperativos econômicos. $\mathrm{O}$ autor mostra que o advento da tecnologia como forma de adentrar no reduto da irrepetibilidade da obra constituída pela aura provocou mudanças inquestionáveis no modo de encarar o Belo da tradição clássica. Isso significa que a posição da obra de arte mudou, porque, ao romper com a tradição enquanto legitimadora da distância ritual, a tecnologia liberta e reativa o objeto artístico pela reprodução. Assim a realidade se torna completamente permeada pela tecnologia.

Tal formulação assegura que Benjamin "[...] não sucumbiu ao equívoco de considerar os meios de reprodução de linguagem apenas como meios de consumo, mas considerou-os simultaneamente como meios de produção" (SANTAELLA, 1990, p. 82). $\mathrm{E}$, assim, afirma "um germe revolucionário desses meios quando trazem um potencial de limitação do monopólio da inteligência burguesa, e de atingimento a amplas camadas com reais possibilidades de socialização de uma cultura popular" (SANTAELLA, 1990, p. 84).

Martin-Barbero (2001) tem a convicção de que a força da Indústria Cultural está em tocar e revelar uma dinâmica profunda da memória e do imaginário, constituidora de matrizes culturais do povo latino-americano ativadas na música, por exemplo, pelo caráter lúdico, de festa, brincadeira, humor, romance, diversão e jogo. Isso leva a uma análise crítica da visão que muitas vezes promove uma dicotomia entre a lógica dos meios (como somente emoção) e a lógica da escola (como somente razão). A arte possibilita um conhecimento de mundo em que interagem as diferentes dimensóes humanas do ato de conhecer.

Cabe refletir com mais vagar sobre a forma como nos relacionamos com a música, qual o papel do receptor no processo de emissão/recepção e as possibilidades emancipatórias das mídias, objetivando entender a contradição dessa relação no que se refere aos objetos midiáticos. 


\subsection{Música e indústria cultural: relação e contradição}

Há no mundo uma natureza musical revezando sons, ruídos e silêncios que nos afetam a partir dos primeiros minutos de vida. Essa força telúrica desde muito cedo nos impregna pela sucessão e freqüência de vibraçōes que estabelecem os graves, agudos, fortes, fracos e timbres variados. Os primeiros balbucios já podem ser contabilizados como melodias de intervalos simples, ou "proto-ritmos" (FRIDMAN, 1988), mais tarde acrescidos de movimentos corporais ritmados, quer por imitação, quer por impulso natural. Traduzido nos ritmos e cadências corporais - assobios, passos, marchas, fala e canto -, esse sentido psicofísico da música parece acompanhar os seres humanos durante a vida, evidentemente resguardando-se as diferenças culturais. A esse caráter performático podem ser atribuídos muitos dos efeitos que a música causa.

Segundo Wisnik (1989, p. 12), a música "fala ao mesmo tempo ao horizonte da sociedade e ao vértice subjetivo de cada um". Há uma correspondência entre corpo/mente e pulsações sonoras, ou seja, a fruição musical encontra eco nas ressonâncias psico-somáticas dos sujeitos. A música é, ao mesmo tempo, silêncio/movimento, alegria/tristeza, "pulsos estáveis e instáveis, ressonâncias e defasagens, curvas e quinas" (WISNIK, 1989, p. 21). Que outra manifestação artística pode se relacionar tão intensamente com físico, intelecto, intuição e emoção? Isso explica talvez a facilidade com que os apelos rítmico/sonoros midiáticos capturam tanto adultos quanto crianças, ainda mais quando acrescidos das imagens.

Essa especificidade na relação humana com a música talvez possa ajudar a entender que o consumo da música midiática como processo inserido e em alguma medida dependente das relaçōes econômico/culturais, como já foi abordado, não é redutível a essas relações. A repetição de certas formas, acordes e modos musicais que são parte de uma cultura e que reproduzem padrões dominantes de ouvir e sentir facilita a familiaridade tão contestada por Adorno.

Quanto ao conceito de massivo, cabe dizer que a tendência de consumo hoje retrata também diferenciações e não só uniformização. Em relação a isso, é importante considerar a questão das subculturas (góticos, skatistas, metaleiros, surfistas, clubers, emo, cowboys, etc.) que se identificam com determinadas formas musicais (funk, emocore, hardcore, heavymetal, rock, pagode, sertaneja, hip-hop, etc.), cujo caráter acentua a formação de uma identidade grupal diferenciada (SUBTIL, 2006). Alguns fatores como idade, etnia e gênero - levam a escolhas que não se identificam tanto assim com um padrão massivo. Embora no cômputo geral os sujeitos pesquisados por Subtil (2003) apresentassem as mesmas preferências, foi possível detectar, no cotidiano, as ressalvas, as nuances e as particularidades que, em música, são próprias das individualidades, das comunidades e dos diferentes grupos (SUBTIL, 2003).

Considere-se, portanto, que os sujeitos receptores têm um papel importante na construção do significado dessas emissões, mediante as múltiplas inter-relações e mediações: 
família, escola, grupos de referência, entre outras. Os estudos sobre recepção mostram não só os limites, mas também as possibilidades emancipatórias da própria mídia. Como se afirmou anteriormente, essa dimensão contraditória decorre, além da relativa autonomia do sujeito receptor, do fato de que a Indústria Cultural, ao mesmo tempo em que veicula um padrão musical muitas vezes simplificado, também socializa obras de arte de valor musical em todos os gêneros: erudito, popular e folclórico. Segundo MartinBarbero (2001), a aproximação que se sobrepõe à distância é uma nova sensibilidade das massas.

Transferir da emissão para a recepção a capacidade de produzir sentidos significa perceber no segundo momento o caráter ativo e produtor de significados na perspectiva do consumo, não apenas como posse e reprodução das relações de força da sociedade, mas como o lugar onde se revela uma determinada competência cultural: "Os 'usos' (...) são inalienáveis da situação sociocultural dos receptores, que reelaboram, ressignificam, ressemantizam os conteúdos massivos conforme sua experiência cultural, a qual dá suporte para esta apropriação" (JACKS, 1999, p. 51).

Apesar do acento pessimista quanto aos efeitos da Indústria Cultural, particularmente em relação à música, os autores frankfurtianos já citados consideram a possibilidade de transformação da semi-formação - que eles creditam às práticas decorrentes de uma racionalidade econômica, instrumental - em formação (ZUIN, 1999). A afirmação "O mal não deriva da racionalização do nosso mundo, mas da irracionalidade com que essa racionalização atua" (HORKHEIMER; ADORNO, 1982, p. 98) alerta para a necessidade de desmistificar a racionalidade vigente sob os imperativos econômicos e culturais da sociedade capitalista. Então, vale a pena trazer ao final esse debate para o campo da educação e dos educadores.

\section{CONSIDERAÇÕES FINAIS - A NECESSÁRIA RELAÇÃO ENTRE FRUIÇÃO E FORMAÇÃO}

Em seus escritos, Adorno e Horkheimer denunciam a mercantilização e a padronização promovidas pela Indústria Cultural e chamam isso de semi-formação, algo que nega a emancipação do sujeito pela possibilidade de autodeterminação. No entanto, essa constatação não exclui a possibilidade da efetivação da cidadania, a humanização dos sujeitos, a produção da sensibilidade e o exercício estético, porque aqui entra em campo o processo de educação.

As expressões "emancipação" e "homens não tutelados" são correlatas à "formação de indivíduos autônomos, independentes, capazes de julgar e de decidir conscientemente" (ADORNO, 1986, p. 99). Para esse autor, a formação significa:

[...] a ousadia de poder raciocinar por si próprio ao mesmo tempo em que se possui publicamente a liberdade para poder criticar as instituiçōes [...] o exercício dessa incumbência de se 
fazer uso público da razão implica a benfeitoria da própria sociedade, pois não se restringe ao indivíduo, mas, sim, revela-se fio condutor básico das instituiçôes sociais (apud ZUIN, 1999, p. 30-31).

Essa visão, para além da dimensão kantiana da razão como preceito instituidor do sujeito, resgata outros significados da racionalidade, como capacidade de julgamento, de crítica, de autodeterminação para o benefício da coletividade, no aperfeiçoamento das instituiçôes. O que está em jogo é o princípio da liberdade e da autonomia (indivíduos) como base para o exercício da cidadania (sociedade).

Nessa perspectiva, a formação também está longe da idéia do usufruto privado dos bens culturais como forma de distinção, usando um termo de Bourdieu (1997), para afirmação de uma identidade isolada. A cultura enquanto valor em si, dissociada das coisas humanas, retira dos bens culturais a vocação de humanidade e universalidade que a impregna.

Um pressuposto basilar é o de que a vivência estética não pode prescindir da reflexão. Segundo Zuin (1999, p. 68):

Para Adorno a possibilidade dessa experiência funda-se na interdependência entre a atividade reflexiva do sujeito e a obra de arte, cuja força expressa as potencialidades que não se reduzem à sua aparência imediata, desvelando a reciprocidade contraditória entre a mímesis e a racionalidade, entre o belo e o necessário.

Importa aqui recusar a afirmação ou a negação pura e simples dos produtos midiáticos, mas reforçar a reflexão como condição para a efetivação da educação dos sentidos e a sensibilização como possibilidade de separar os aspectos mercadológicos de uma experiência estética significativa. O papel das instâncias educadoras é fazer com que os sujeitos percebam qual o significado histórico, formal, temático da música e experienciem o processo artístico musical pela experimentação e apreciação de obras de todos os tempos e lugares, com o aporte das diferentes emissões midiáticas disponíveis. Ampliar os repertórios musicais é uma ação educativa possível e necessária, que independe de formação musical específica dos professores, dada a facilidade de acesso tanto às informaçôes quanto aos aparatos tecnológicos para a audição.

Adorno (1995, p. 121) declara: "A educação tem sentido unicamente como educação dirigida a uma auto-reflexão crítica”. Mais adiante, acrescenta:

A educação seria impotente e ideológica se ignorasse o objetivo de adaptação e não preparasse os homens para se orientarem no mundo. Porém, ela seria igualmente questionável se ficasse nisso, produzindo nada além [...] de pessoas bem ajustadas, em conseqüência de que a situação existente se impõe precisamente no que tem de pior (ADORNO, 1995, p. 143).

Subtil (2003) deparou-se em sua pesquisa com o fato de que na escola há um vazio de significação da arte - e, em especial, da música - e muito mais "adaptação" ao status 
quo do que seria desejável. Nas falas dos alunos evidenciou-se uma vontade de conhecimento e de fruição musical ativa, sem uma resposta correspondente dos professores e da organização curricular. De maneira geral prevaleciam, pelo menos até aquele momento (2003), práticas já desgastadas pelo uso: momentos cívicos, comemoraçóes folclóricas com as cantigas referentes às datas, ou repetição pura e simples das músicas do momento, com os mesmos gestos e a mesma performance (incluindo-se as roupas) dos hits preferidos e dos artistas cultuados.'

Quanto a isso cabem mais algumas considerações de Adorno (1986, p. 131), quando diz: "O sentido musical é o Novo - algo que não pode ser subsumido sob a figuração do conhecido, nem a ele ser reduzido, mas que brota dele, se o ouvinte vem ajudá-lo". Essa é uma contribuição importante do autor, ao afirmar o novo como o verdadeiro "sentido musical de uma música”, sem, no entanto, desconsiderar o pré-existente, o já conhecido, de domínio público, concedendo papel ativo ao ouvinte como um sujeito que age sobre a música, que a tem como objeto do conhecimento e que não se deixa levar apenas pelo reconhecimento.

Pode-se inferir que o negativo não é necessariamente a música "ligeira", "de massa", "popular" e de audição generalizada, em detrimento da música "séria", "erudita” e signo de distinção, mas aquela que não contém um traço sequer de inovação, contribuindo para uma audição passiva.

Por conseguinte, as vivências musicais decorrentes da mídia não devem ficar apenas e sempre no re-conhecimento, mas é necessário desenvolver a percepção e a comparação no "funk" e no "rap", por exemplo, da inovação e da repetição. É importante situar o contexto de origem dessas obras citadas como exemplos, a forma como elas se instalaram de empréstimo nas culturas atuais e de que modo nos afetam hoje, no local e no espaço que ocupamos. Aqui, sem dúvida, entra a ação da escola.

Se é possível entender que a música midiática é um processo formal, com características próprias não só da música mas também da performance (audiovisual), cabe investigar a fundo como esse processo se constitui, o que da sociedade está presente ou ausente em seu interior e o que da experiência humana se pode apreender desse objeto da cultura contemporânea. Essa formação tem a ver com a educação dos próprios professores, os quais, em última análise, deveriam passar de consumidores a apropriadores ativos das músicas que partilham de igual para igual com seus alunos.

Para finalizar, vale como um alerta para além dos professores, a reflexão de Zuin (1999, p. 158):

O resgate do sentido da emancipação talvez esteja também atrelado à necessidade de que uma concepção educacional crítica incentive a auto-reflexão daqueles que se julgam educados, mas que colaboram decisivamente tanto para sua própria debilidade quanto para a dos outros. 


\section{Notas}

1. O termo mídia significa meios, grafia brasileira da pronúncia inglesa de media (latim), plural de medium (meio). Para Belloni (2001, p. 45), durante os anos 90, houve "uma evolução em direção ao neologismo mídias, um duplo plural, que parece ter a função de ampliar e tornar flexível o conceito". Neste trabalho, o termo será utilizado tanto no plural quanto no singular.

2. Neste texto, a expressão música midiática será usada como uma forma musical que é característica do universo cultural da televisão pela associação dos aspectos musicais - o ritmo, a melodia e a letra - mixados aos elementos visuais midiáticos e à performance (interpretação).

3. MPB é uma sigla, criada na década de 60 , para músicas que, por terem um caráter mais sofisticado (como as da chamada bossa-nova), diferenciavam-se das composições populares oriundas dos morros e das periferias.

4. Esse termo não é apenas sinônimo de consumo; significa também "gozo, posse, usufruto", conforme Dicionário Escolar da Língua Portuguesa. Zuin (1999) concebe fruição estética "no sentido etimológico de percepção, ou seja, a fruição perceptiva que fundamenta o desenvolvimento das relações entre a consciência e o mundo fenomênico - proveniente da experienciação das qualidades que compõem o gênero humano, tais como a beleza e a justiça" (p. 40). $\mathrm{O}$ autor acrescenta que "Em função do próprio desenvolvimento das forças produtivas da Antiguidade, a fruição da pureza, da beleza e da justiça ficou restrita a um determinado grupo social" (idem).

5. Para Canclini (1996, p. 53, grifos do autor), consumo "é o conjunto de processos socioculturais em que se realizam a apropriação e os usos dos produtos (...) é compreendido, sobretudo, pela sua racionalidade econômica".

6. Alguns autores contemporâneos acrescentam conclusões baseadas em pesquisas empíricas sobre essa nova definição de aproximação dos sujeitos com os objetos culturais. Babin; Kouloumdjian (1982) e Belloni (1995), entre outros, consideram que a cultura do som, da imagem e dos meios eletrônicos impregna os modos de experimentar e conhecer o mundo. McLuhan (1989) constata o envolvimento profundo e sensorial com os meios, chegando a afirmar que o meio é a mensagem. Kerkhove (1997) diz que a televisão produz um efeito de "sentido pressentido", isto é, fala primeiro ao corpo, provocando uma antecipação sensorial do significado que será atribuído mais tarde (p. 43).

7. Para Horkheimer e Adorno (1982, p. 182). o sentido de amusement (diversão) reduz arte, divertimento e cultura a um denominador comum, produzindo a alienação necessária à continuidade do sistema.

8. O autor afirma que o argumento apresentado na citação foi usado por Marcuse, na obra "O caráter afirmativo da cultura”, de 1937, esboçando a característica central da arte burguesa: ela é - ao mesmo tempo - alienação e protesto (SILVA, 1999, p. 31).

9. Acrescente-se uma prática que está se afirmando nas escolas, que é o canto e a audição de "músicas - mensagem" de caráter religioso. Isso tem a ver com a veiculação do gospel, música disseminada nos programas televisivos das religiōes evangélicas e católica. 


\section{Referências}

ADORNO, W. T. Sobre música popular. In: COHN, G. (Org.). Theodor Adorno - Sociologia. São Paulo: Ática, 1986. p. 115-146. (Coleção Grandes Cientistas Sociais).

. Teoria estética. Lisboa: Martins Fontes, 1988.

. O fetichismo na música e a regressão da audição. In: ADORNO, W. T. Textos Escolhidos. Tradução de Zeljko Loparié. São Paulo: Nova Cultural, 1991. p. 76-105.

. Educação e emancipação. Trad.: Wolfgang Leo Maar. São Paulo: Paz e Terra, 1995.

BABIN, P.; KOULOUMDJIAN, M. F. Os novos modos de compreender - a geração do audiovisual e do computador. São Paulo: Edições Paulinas, 1982.

BELLONI, M. L. Escola versus televisão: uma questão de linguagem. Educação \& Sociedade, Campinas: Cedes, n. 52, p. 571-583, dez. 1995.

. O que é mídia-educação. Campinas: Editores Associados, 2001.

BENJAMIN, W. A obra de arte na época da sua reprodutibilidade técnica. In: LIMA, Luis Costa. Teoria da cultura de massa. 3. ed. Rio de Janeiro: Paz e Terra, 1982. p. 206-244.

et al. Benjamin, Habermas, Horkheimer e Adorno - textos escolhidos. Trad.: José

Lino Grünnenwald. 2. ed. São Paulo: Abril Cultural, 1983. (Coleção Os Pensadores).

BOURDIEU, P. O poder simbólico. São Paulo: Edifel, 1989.

. La distinción - criterios y bases sociales del gusto. Buenos Aires: Taurus, 1998.

. A economia das trocas simbólicas. 3. ed. São Paulo: Perspectiva, 1992.

Razões práticas - Sobre a teoria da ação. 2. ed. Campinas: Papirus, 1997.

CANCLINI, N. G. A socialização da arte - teoria e prática na América Latina. 2. ed. São Paulo: Cultrix, 1984.

EdUFRJ, 1996.

. Culturas híbridas. São Paulo: Edusp, 1997.

CHAUÍ, M. Conformismo e resistência - aspectos da cultura popular do Brasil. São Paulo: Brasiliense, 1985.

COELHO, T. O que é indústria cultural. São Paulo: Brasiliense, 1980.

DUFRENNE, M. A estética e as ciências da arte. Lisboa: Livraria Bertrand, 1976, v. 1.

A estética e as ciências da arte. Lisboa: Livraria Bertrand, 1976, v. 2.

ECO, H. Apocalípticos e integrados. São Paulo: Perspectiva, 1976.

FISHER, E. A necessidade da arte. 9. ed. Rio de Janeiro: Guanabara, 1987.

FRIDMAN, R. El nascimiento de la inteligencia musical. Buenos Aires: Editorial Guadalupe, 1988.

HORKHEIMER, M.; ADORNO, T. W. A indústria cultural - o iluminismo como mistificação das massas. In: LIMA, Luis Costa. Teoria da cultura de massa. 3. ed. Rio de Janeiro: Paz e Terra, 1982. p. 159-204. 
JACKS, N. Querência. Cultura regional como mediação simbólica - um estudo de recepção. Porto Alegre: EdUFRGS, 1999.

KERCKHOVE, D. de. A pele da cultura - uma investigação sobre a nova realidade eletrônica. Santa Maria da Feira: Relógio D’Água Editores, 1997.

MARTIN-BARBERO, J. Dos meios às mediações - comunicação, cultura e hegemonia. 2. ed. Rio de Janeiro: EdUFRJ, 2001.

MCLUHAN, M. Os meios de comunicação como extensões do homem. 5. ed. São Paulo: Cultrix, 1989.

MICELLI, S. A noite da madrinha. 2. ed. São Paulo: Perspectiva, 1982.

A força do sentido (introdução). In: BOURDIEU, Pierre. Economia das trocas simbólicas.

3. ed. São Paulo: Perspectiva, 1992. p. I-XXV.

MIRANDA, V. S de. Estética e indústria cultural em Adorno. Educação em Debate, Fortaleza, v. 20, n. 35, p. 23-28, 1998.

NUNES, B. Introdução à filosofia da arte. São Paulo: São Paulo Editora, 1966.

OLIVEIRA, J. R. de. Indústria cultural e mídia: Limites e perspectivas para a educação no debate entre Benjamim e a Escola de Frankfurt. Trabalho apresentado na 21 a Reunião Anual da Anped, 1998.

SANTAELLA, L. (Arte \& Cultura) equívocos do elitismo. 2. ed. São Paulo: Cortez, 1990.

SILVA, R. C. A atualidade da crítica de Adorno à indústria cultural. Educação e Filosofia, Uberlândia, v. 13 , n. 25 , p. $27-42$, jan./jun. 1999.

SUBTIL, M. J. D. A apropriação e fruição da música midiática por crianças de quarta série do ensino fundamental. Florianópolis, 2003. 227 f. Tese. (Doutorado em Engenharia de Produção) Programa de Pós-Graduação em Engenharia de Produção, Universidade Federal de Santa Catarina. . Música midiática e o gosto musical das crianças. Ponta Grossa: EdUEPG, 2006.

VÁZQUEZ, A. S. As idéias estéticas de Marx. 2. ed. Rio de Janeiro: Paz e Terra, 1978.

WISNIK, J. M. O som e o sentido - uma outra história das músicas. São Paulo: Companhia das Letras, 1989.

ZUIN, A. A. S. Indústria cultural e educação - o novo canto da sereia. Campinas: Autores Associados, 1999. 


\section{Reflections on art and culture industry}

\section{Abstract}

This paper discusses the relationship between art (especially music) and cultural industry, taking into consideration the contradictions inherent to this idea pointed out by the Frankfurtian authors. Understanding the cultural field in which musical objects are situated as a space of relationships and struggles for symbolic power, the erudite, popular and mass cultures are discussed. The hybridism of these concepts is emphasized considering the imperatives of the capitalist consumer society. The paper also presents historical aspects related to the production, circulation and artistic consumption enhancing the new possibilities of fruition by the technical reproducibility of the aesthetical objects. Finally, it presents a reflection on the necessary relationship between fruition, consumption and formation from the Adornian point of view which considers the substitution of the instrumental dimension of reason by the emancipatory dimension as a condition for des-alienation.

Keywords: Art. Cultural Industry. History of aesthetical production. Formation.

\section{Réflections sur l'art et l'industrie culturelle}

\section{Résumé}

Ce travail discute la relation entre art (spécialement la musique) et l'industrie culturelle, en prenant en considération les contradictions inhérentes à cette idée formulée par les auteurs frankfurtiens. Comprennant le champs culturel dans lequel se situe les objets musicaux comme un espace de relations et de disputes pour le pouvoir symbolique, l'on discute les genres érudit, populaire et de masse, mettant en relief l'hybridisme de ces concepts, tenant compte des impératifs de la société capitaliste de consomption. L'on fait aussi l'historique dans le texte de la production, circulation et consomption artistique, mettant l'emphase sur les nouvelles possibilités de fruition par la reproductibilité technique des objets esthétiques. Pour fin, l'on présente une réflexion sur la nécessaire relation entre la fruition, consomption et formation à partir du point de vue adornien, qui considère la substitution de la dimension instrumentale de la raison par la dimension émancipatoire comme condition pour la désaliénation.

Mots clefs : Art. Industrie culturelle. Histoire de la production esthétique. Formation.

\section{Reflexiones acerca del arte y del industria cultural}

Resumen

En el presente texto se discute la relación entre arte - particularmente la música - e indústria cultural, considerándose las contradicciones inerentes a esa idea formulada por los autores frankfurtianos. Comprendéndose el campo cultural en que se sitúan los objetos musicales como un espacio de relaciones $y$ de disputas por el poder simbólico, se discuten los géneros erudito, popular y masivo apuntándose para el hibridismo de eses conceptos, considerando los imperativos de la sociedad capitalista de consumo. También se aborda en el texto la historicidad de la producción, circulación y consumo artístico, enfocándose nuevas posibilidades de fruición por la reproducción técnica de los objetos estéticos. Por fin, se presenta una reflexión acerca de la relación necesaria entre fruición, consumo y formación a partir del punto de vista adorniano, que considera la sustitución de la dimensión instrumental de la razón por la dimensión emancipatoria como condición para la desalienación.

Palabras-clave: Arte. Industria cultural. Historia de la producción estética. Formación 
